INTERNATIONAL JOURNAL OF MULTIDISCIPLINARY RESEARCH AND ANALYSiS

ISSN(print): 2643-9840, ISSN(online): 2643-9875

Volume 04 Issue 11 November 2021

DOI: 10.47191/ijmra/v4-i11-20, Impact Factor: 6.072

Page No.- 1621-1625

\title{
Perceptual Feedback of Undergraduate Medical Students on Effectiveness of AETCOM (Attitude, Ethics and Communication) Session in Foundation Course
}

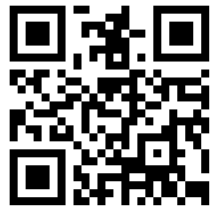

\author{
Dr. A.T. Sathiyavinotha MD', Dr. A.Vijayamathy MD², Dr. S. Velarul MSc (Medical Pharmacology) ${ }^{3}$, \\ Dr. S. Bhuvaneshwari MD", Dr. M.S. Umamageswari MD ${ }^{5}$, Dr. S. Jeevithan MD $^{6}$ \\ 1,2,3,4,5,6 KMCH Institute of Health Sciences \& Research, Coimbatore, Tamil Nadu, India.
}

Corresponding author: Dr. A.T. Sathiya Vinotha

Address: 52, Duraisamy nagar, Goldwins, Coimbatore-14.

ABSTRACT: Introduction: In accordance with National Medical Commission (NMC) recommendation, one month foundation Course was conducted in our institution in August 2019.The present study was conducted to seek the opinion of the students regarding pertinence of the Attitude, ethics and communication (AETCOM) session in the course to enable revisions to be made in designing the course for the subsequent sessions, to make it more efficacious and student-oriented.

Methods: First MBBS students joined in the year 2019-20 batch were involved in the study. The students were divided into three groups and three hours sessions have been taken separately for three consecutive days. The Teaching Schedule of AETCOM session was systematically designed with theory and case scenarios. At the end of the session all the students were provided a feedback questionnaire based on Likert scale and the responses were collected.

Statistical analysis: The data collected was analysed using SPSS version 23 and simple mean and proportions were calculated.

Results: $53.9 \%$ of the students perceived the AETCOM session discussed with case scenarios as good and $50 \%$ of the students were given feedback on overall session as good.

Conclusion: The AETCOM session in foundation course has largely been perceived in a positive way by the students with some difference in opinion concerning relevance of certain topics. However, it has to be confirmed with further studies.

KEYWORDS: AETCOM, Foundation course, Feedback

\section{INTRODUCTION}

Congruous knowledge on Attitude, Ethics and Communication Skills with the patients plays a vital role in prosperity of medical professionals. So, from first MBBS itself AETCOM module has been formulated to train the medicos as a component of their undergraduate course. The paramountcy of this training course will reflect in to more efficient interns, who are patient-oriented, ameliorated in attitude and communication to learn and gain experience for a better clinical substratum. ${ }^{1}$ The medical council additionally stressed the paramountcy of Attitude, Ethics and communication and the incipient curriculum changes had come in to effect from 2019-20. Until recently Indian medical graduate is focused only in passing exams and getting a degree, and the curriculum did not provide scope for competency-based education for under graduate students. Now medical council has introduced changes in the curriculum, in which paramountcy being given to Competency based Medical education. Medico-Patient communication is a teachable adeptness. Training programme at medical student's level prospers in amending their communication skills. The Medical Council of India $(\mathrm{MCl})$ expects a medico to be competent enough in communicating with the patients adequately, affectively, sensitively and reverentially. It has proposed in its document (Vision-2015), a substructure course for undergraduate students in first two months of first year of MBBS, which includes an orientation towards learning the communication skills. ${ }^{2}$ The main purport is to train the under graduate students in different competencies, they require to acquaintance to be a competent medical graduate including attitude, ethics and communication. $\mathrm{MCl}$ recommended to discuss the AETCOM competencies with different case scenarios. As a component of the foundation course, sessions on AETCOM is 


\section{Perceptual Feedback of Undergraduate Medical Students on Effectiveness of AETCOM (Attitude, Ethics and Communication) Session in Foundation Course}

included for the first time in 2019-20 UG MBBS curriculum. So perceptual feedback of Attitude, Ethics and Communication Skills (AETCOM) session with case scenarios by first MBBS students as a cognition implement in their foundation course is obligatory. The revised GMR 2017 document engenders roles for the graduate that transcends the traditional cognizance and adeptness components. In particular, it integrates roles - clinician, leader and member of the health care team, communicator, lifelong learner and professional - which call for learning and skills not addressed by the traditional syllabus. The entire concept of AETCOM module lies on the fundamental principle that transmuting a person's attitude can transmute his or her deportment. ${ }^{3}$ The Cognitive components of attitude are more fundamental and constant over time and more proximately connected to rudimentary values. Behavioural attitudes are manifestations of underlying cognitive and affective attitudes. Ethical dimensions play a crucial role in behavioural evolution. Studies from south Asian countries depict that medicos lack cognizance and entelechy of the subsistence of institutional ethics committee and its exact role. ${ }^{4}$

Students show mixed replications both desirable and undesirable in cognation to questions regarding different facets of rudimentary ethical reasoning in their professional lives and the rudimental building block of good communication is the feeling that every human being is unique and of value. ${ }^{5,6}$ To truncate the mistakes better communication between medico and patient is needed. Communication skills are like fine arts in medical practice. Professionalism demands efficacious communication skills. There are many incipient key areas recommended in the AETCOM module that are identified for implementation across the entire duration of the undergraduate medical (MBBS)course. ${ }^{7,8}$ The methodology recommended in the AETCOM is 'Hybrid Problem Oriented approach' utilizing mostly case scenarios. The case scenarios are predicated on authentic life or simulated cases which trigger a plethora of cerebrated process and discussion among students, facilitated by faculty in diminutive groups or buzz sessions. They sanction high calibre of interactivity, inspirit quandary solving skills. In integration to quandary solving skills, case discussions promote collaborative learning, team collaboration, reflection and self-directed learning. ${ }^{9}$

Customarily a case scenario involves two or more learning sessions in minuscule groups cumulated with an intervening lecture session. A case is introduced into a diminutive group and the facilitator facilitates a diminutive group discussion where, initial reactions of the group to the case is obtained, the underlying ethical, licit and societal principles of the case are elicited, learning objectives for the case are developed. A hybrid problemoriented approach is one of the most efficacious ways for students to explore the sundry facets of "real life issues" that will confront them in their vocations. ${ }^{10}$ Discussion of the AETCOM session with case scenarios is highly recommended by the MCI. Since 201920 UG MBBS students were the first batch to undergo this foundation course assessment of the perceptual feedback of students on AETCOM session discussed with case scenarios is needed.

\section{MATERIALS \& METHODS}

This is a cross sectional study conducted over a period of one month involving first year MBBS students who joined in the year 2019-20 in KMCH Institute of Health Sciences \&Research, Coimbatore, India.150 students were included in this study. Approval from Institutional Human Ethics Committee was obtained.

\section{METHOD}

First MBBS students joined in the year 2019-20 batch were involved in the study. The students were divided into three groups and sessions have been taken discretely for three consecutive days for three hours each day. The Edification Schedule of AETCOM session was systematically designed with theory and case scenarios. After an icebreaking session for 20 minutes, the remaining two hour $\mathbf{4 0}$ minutes was divided into two as $\mathbf{4 0}$ minutes for theory class on exordium to AETCOM and two hours for case scenario discussion. Each day after icebreaking and theory session the students were divided into four groups by ask them to numbering from 1-4. Each group a categorical case scenario was given. Four case scenarios predicated on attitude, ethics and communication were discussed. At the terminus of the session all the students were provided a feedback questionnaire predicated on Likert scale. The questionnaire contains initial demographic data with seventeen questions of two sections: 1) nine questions regarding perception on AETCOM session which includes concept, attention span, interest, usefulness, retainability of information, depth of cognizance on verbalizers 2) eight question regarding feedback on overall AETCOM session which includes icebreaking session, objectives, edifying methods, learning from peers, time allotment, environment. The responses from the students were collected.

\section{STATISTICAL ANALYSIS}

The data collected was analysed using simple mean and proportions. The maximum and minimum response for each question was analysed separately. SPSS software version 23 was used for data analysis. 


\section{Perceptual Feedback of Undergraduate Medical Students on Effectiveness of AETCOM (Attitude, Ethics and Communication) Session in Foundation Course}

\section{RESULTS}

Among the 150 students (2019 batch) who were supposed to join the MBBS course, most (35) of the first-year students were tardy joining for the foundation course, so 115 students only were included in the study. All those 115 students were given the same questionnaire with nine questions on perception and eight questions on feedback of the overall AETCOM session. No student was given strongly disagree or disagree for the questions on perception of AETCOM session with case scenarios. Some students did not give any response for some questions, for those questions the response was marked as zero. The group consisted of 61 females (53\%) and 54 males (47\%).

The questions were rated on a five-point Likert-type scale ranging from strongly disagree (score -1) to strongly agree(score-5) with 3 being neutral or undecided. The questions on feedback were rated on a four-point Likert-type scale ranging from 1- Not at all,2can't say,3- To some extent, 4-fully. The percentage responses for the questions is shown in Table 1 . While reporting the results in text, the perceptual feedback has been reported as mild $(<30 \%)$, moderate $(31-45 \%)$ and good $(46-100)$. In this study $6.1 \%(n=7)$ of students perceived AETCOM session as mild, $40 \%(n=46)$ felt as moderate and $53.9 \%(n=62)$ considered the session as good.2.6\% $(n=4)$ of the students considered feedback on AETCOM session as mild, $44.4 \%(n=55)$ felt as moderate and $50 \%(n=56)$ considered the overall session as good. (Table 2)

\section{DISCUSSION}

The medical education system requires incipient approaches in shaping the medical graduates as an adept medico. The medical inculcation system in India is now under reproval by its stakeholders. The Indian Medical graduates mainly lagging behind in right attitude towards patients, diffidence, communication skills and ethical literacy. Medical Council of India (MCI) has introduced an undergraduate medical inculcation programme designed to engender "Indian Medical Graduates" with competencies (erudition, skills, and attitude) to play their role as good health care providers. To work in primary care setting both in urban as well as in rural areas of our country it is obligatory to engender medicos with requisite adeptness, erudition, values \&attitudes. A medico should be able to play in the roles of a clinician, bellwether, communicator, perennial learner and professional. ${ }^{11}$ This incipient curriculum introduced by the $\mathrm{MCl}$ will avail the medicos to undergo competency predicated learning to acquire the above verbalized competencies at the terminus of the MBBS course.

It includes attitude, ethics and communication (AETCOM) competencies. It offers a framework of competency predicated learning in the AETCOM domains. The proposed MCI's AETCOM has case-predicated modules designed to be transacted over a period of four professional years in a longitudinal manner. Earlier it was attitude and Communication Module (ATCOM) in 2015 and later ethical component was included and it was renamed as AETCOM in 2017. This was yare by the Reconciliation Board of $\mathrm{MCl}$ and has been approved for publication by the Academic Committee and the Executive Committee. To check the usefulness of the AETCOM module tribulations were conducted at Regional and Nodal Centres of the $\mathrm{MCl}$. Afore implementing into the MBBS curriculum MCl trained the faculty of medical colleges through its nodal and regional centres. ${ }^{12}$ Since 2019-20 UG MBBS students was the first batch who underwent this AETCOM session in foundation course we analysed the perceptual feedback received from the students for better understanding of their concerns regarding AETCOM.

Regarding questions on perception $53.9 \%$ of the students considered as good which shows the desideratum of the case predicated scenarios included in the AETCOM session. In future the AETCOM session can be further amended by utilizing technology availed edifying learning like online case predicated scenarios, e-portfolios which would increment interest in subjects among students as well as preserve time. Albeit many more incipient technological advancements transpire every day, it is underutilised in the field of medical education. ${ }^{13}$

The feedback of the overall AETCOM session was considered as good by $50 \%$ of the students which shows the session can be further facilitated by videography, movies and quizzes. Thus, to ameliorate felicitous attitude towards the subject technology availed learning can be implemented. ${ }^{14}$

Perception and feedback revealed that the participants appreciated the session and many have acceded the concept was understandable, session interactive and subsidiary. This study conducted among students in the foundation course provided the faculties an opportunity to engender incipient conceptions and suggestions to refine the content and structure of AETCOM session so that in future it will avail to implementing the AETCOM more efficaciously to the students.

\section{CONSTRAINTS}

The inhibitions of this study include the fact that we were unable to objectively document gains in cognizance and skills as a result of the feedback program. The results of this is not generalizable. 
Perceptual Feedback of Undergraduate Medical Students on Effectiveness of AETCOM (Attitude, Ethics and Communication) Session in Foundation Course

\section{CONCLUSION}

The AETCOM session in foundation course has largely been perceived in a positive way by the students with some difference in opinion concerning pertinence of certain topics. This study is a valuable implement for faculties to amend their edification competencies pertaining to AETCOM.

\section{ETHICAL APPROVAL}

The project is approved by the Institute Human Ethics Committee, $\mathrm{KMCH}$ Institute of Health Sciences and Research, Coimbatore, India (Ethical committee number: 03/IHEC/2020)

\section{ACKNOWLEDGEMENT}

We would like to thank all the undergraduate students who have rendered their voluntary consent for participating in the process.

\section{REFERENCES}

1) Perception of medical students about Communication Skills Laboratory (CSL) in a rural medical college of central India. J Clin Diagn Res. 2015;9(12): JC01-JC04.

2) Medical Council of India. VISION 2015 (Internet). New Delhi Mar 2011. Jagzape TB, Jagzape AT, Vagha JD, et al.

3) Medical Council of India (MCI) Attitudes, Ethics and Communication . (AETCOM) Modules 2016. 5

4) Choudhary A, Gupta V. Teaching communication skills to medical students: introducing the fine art of medical practice. Int J Appl Basic Med Res 2015;5(Suppl1):4144.

5) Komattil R, Hande SH, Mohammed CA, et al. Evaluation of a personal and professional development module in an undergraduate medical curriculum in India. Korean J Med Educ 2016;28(1):117-121.

6) Ashin S, Shahid A, Gondal GM. Teaching communication skills and medical ethics to undergraduate medical students. J Adv Med \& Prof 2013;1(3):72-76.

7) Modi JN, Anshu-Chhatwal J, Gupta $P$, et al. Teaching and assessing communication skills in medical undergraduate training. Indian Pediatr 2016;53(6):497504.

8) Naineni K, Rao GVR, Saie U, et al. Addressing the challenges of training in communication skills in medicine in India. Journal of Research in Medical Education and Ethics 2016;6(1):10-14.

9) Adkoli B.V. Assessment of professionalism and ethics. Journal of Education Technology in Health Sciences.2019;6(1): 2 9.

10) Anandakrishnan N, Karthikeyan P, Jagmohan R, Pulimoottil DT, Ravi shaker M, Adkoli BV, et al. SBV Model of Competency Based Learning and Training (COBALT) For Post Graduate Education. Ann SBV 2017;6(1):5-

11) Andhra Medical College. ATCOM = the new MCI Attitudes \& Communications Module for $\mathrm{MBBS}$ students [Internet]. $\mathrm{MCl}$ Regional Centre Vizag. 2016 [cited 30 August 2018].

12) Mitra J, Saha I. Attitude and communication module in medical curriculum: rationality and challenges. Indian J Public Health. 2016;60(2):95. https://doi.org/10.4103/0019-557X.184537

13) Yardley S, Teunissen PW, Dornan T. Experiential learning: AMEE Guide No. 63. Med Teach. 2012;34(2): e102-15.

14) Zayapragassarazan Z, Kumar S. Active learning methods. NTTC Bull. 2012;19(1):3-5.

Table 1. Questionnaire with response count in percentage.

\begin{tabular}{|l|l|l|l|l|l|l|}
\hline S.No & \multicolumn{2}{|c|}{ Questions (Perception) } & \multicolumn{5}{c|}{ Response count in \% } \\
\cline { 3 - 7 } & & $\begin{array}{c}\text { Strongly } \\
\text { Agree (5) }\end{array}$ & $\begin{array}{c}\text { Agree } \\
(4)\end{array}$ & $\begin{array}{l}\text { Neutral } \\
(3)\end{array}$ & $\begin{array}{l}\text { Disagree } \\
(2)\end{array}$ & $\begin{array}{l}\text { Strongly } \\
\text { Disagree (1) }\end{array}$ \\
\hline 1$)$ & The concept of AETCOM is acceptable & 65 & 22 & - & - & - \\
\hline 2$)$ & Attention span was good during this session & 43 & 37 & 7 & & \\
\hline 3$)$ & $\begin{array}{l}\text { This session created genuine interest in } \\
\text { AETCOM }\end{array}$ & 46 & 36 & 5 & & \\
\hline
\end{tabular}


Perceptual Feedback of Undergraduate Medical Students on Effectiveness of AETCOM (Attitude, Ethics and Communication) Session in Foundation Course

\begin{tabular}{|c|c|c|c|c|c|c|c|}
\hline \multirow{2}{*}{ 4) } & \multirow{2}{*}{$\begin{array}{l}\text { This session was interactive } \\
\text { This session will be useful as an Indian } \\
\text { medical graduate }\end{array}$} & \multirow{2}{*}{\begin{tabular}{|l|}
66 \\
61 \\
\end{tabular}} & 17 & \multicolumn{3}{|l|}{3} & \\
\hline & & & 22 & 3 & & & \\
\hline 6) & $\begin{array}{l}\text { The information provided during the } \\
\text { session will be retainable }\end{array}$ & 36 & 48 & 3 & & & \\
\hline 7) & $\begin{array}{l}\text { The depth of the knowledge of the speakers } \\
\text { on the respected topic was adequate }\end{array}$ & 48 & 31 & \multicolumn{2}{|l|}{8} & & \\
\hline 8) & $\begin{array}{l}\text { The session on Introduction to AETCOM was } \\
\text { understandable }\end{array}$ & 40 & 41 & \multicolumn{2}{|l|}{6} & & \\
\hline 9) & $\begin{array}{l}\text { The session will boost your confidence as an } \\
\text { Indian medical graduate }\end{array}$ & 51 & 34 & \multicolumn{2}{|l|}{9} & & \\
\hline \multirow[t]{2}{*}{ S.No } & \multirow[t]{2}{*}{ Question (Feedback) } & \multicolumn{6}{|c|}{ Response count in \% } \\
\hline & & $\begin{array}{l}\text { Fully } \\
(4)\end{array}$ & \begin{tabular}{|c|} 
To some \\
Extent (3)
\end{tabular} & \multicolumn{2}{|c|}{$\begin{array}{l}\text { Not at all } \\
(2)\end{array}$} & & $\begin{array}{l}\text { Can't say } \\
\text { (1) }\end{array}$ \\
\hline 1. & $\begin{array}{l}\text { How much did you enjoy the ice breaking } \\
\text { session? }\end{array}$ & 73 & 14 & & & & \\
\hline 2. & Did the session meet its learning objectives? & 56 & 29 & & & 1 & \\
\hline 3. & $\begin{array}{l}\text { Was the content delivered using appropriate } \\
\text { teaching methods? }\end{array}$ & 69 & 17 & & & & \\
\hline 4. & $\begin{array}{l}\text { Was equal opportunity given to you during the } \\
\text { session? }\end{array}$ & 72 & 14 & 2 & ? & & \\
\hline 5. & $\begin{array}{l}\text { Was there a scope to learn from your peers } \\
\text { during the session? }\end{array}$ & 52 & 35 & & & & \\
\hline 6. & $\begin{array}{l}\text { Was there enough content for the time } \\
\text { allotted? }\end{array}$ & 64 & 21 & 1 & L & 1 & \\
\hline \multirow[t]{6}{*}{7.} & \multicolumn{7}{|l|}{$\begin{array}{l}\text { Was the training environment conducive to } \\
\text { learning }\end{array}$} \\
\hline & a) Quiet, & 48 & 31 & 9 & 9 & & \\
\hline & b) Well-lighted & 77 & 9 & & & & \\
\hline & c) Air conditioning, & 12 & 20 & 44 & 14 & 9 & \\
\hline & d) Ventilation, & 57 & 28 & 1 & t. & 1 & \\
\hline & e) Audio-Visual aids & 64 & 22 & 1 & L & & \\
\hline 8. & Did the session conclude on time & \multicolumn{6}{|l|}{$\begin{array}{l}\text { a. Yes- } 85 \\
\text { b. No- } 2\end{array}$} \\
\hline
\end{tabular}

Table 2. Response grading in percentage for perception \& feedback

\begin{tabular}{|l|l|l|l|l|}
\hline Questions & Perception & Fee & dback \\
\hline Grade & Number & Percentage (\%) & Number & 2.6 \\
\hline Mild (<30\%) & 7 & 6.1 & 4 & 44.4 \\
\hline Moderate (31-45\%) & 46 & 40 & 56 & 50 \\
\hline Good (46-100\%) & 62 & 53.9 & 55 & \\
\hline
\end{tabular}

